\title{
Towards a Legislative Reform of the Doctrine of Doli Incapax Under the Nigerian Criminal Code Act
}

\author{
Afolasade A. ADEWUMI, Ph.D ${ }^{1^{*}} \quad$ Victor O. ADENEKAN ${ }^{2}$ \\ 1.Senior Lecturer, Department of Jurisprudence \& International Law, Faculty of Law, University of Ibadan, \\ Ibadan, Nigeria. \\ 2. LL. B University of Ibadan, Ibadan, Nigeria
}

\begin{abstract}
The New King James Version of the Holy Bible states in Proverbs 22:15 that, 'foolishness is bound in the heart of a child, but the rod of correction shall drive it far from him'. When a child due to this inherent folly that pervades his heart, commits a wrong, some of the pertinent questions that may be asked include: Should such child be punished for the wrong committed? How can it be established that the child asides having demonstrated a guilty act had, at the time of the commission of the wrong, a guilty mind? These are some of the questions which this paper attempts to answer while examining criminal responsibility of children in the Nigerian legal system with a careful consideration of Section 30 of the Criminal Code Act which provides for the defence of immature age, otherwise known as the doctrine of doli incapax. In its analysis, this paper submits that although the inclusion of a statutory provision for the defence of immature age in the Criminal Code Act is quite laudable, there are some inconsistencies inherent in the tripartite provisions of Section 30 of the Criminal Code which do not conform to the dictates of logic, common sense and the realities of the Nigerian society. Thus, comparing the Criminal Code with the Penal Code of Northern Nigeria, this paper suggests that there is an urgent need for a legislative amendment of Section 30 of the Criminal Code.
\end{abstract}

Keywords: doli incapax, criminal responsibility, minimum age of criminal responsibility, Nigerian Criminal Code Act, Nigerian Penal Code.

DOI: $10.7176 / \mathrm{JLPG} / 95-05$

Publication date:March $31^{\text {st }} 2020$

\section{Introduction}

According to Dubber, (Dubber 2000) criminal law is concerned with providing an answer to the singular question: 'who is liable for what?' Where an individual is found guilty of a crime, the court must base its conviction on the ground that it found the defendant guilty of the offence with which he/she was charged. Thus, criminal law can be aptly summarised into the creation of offences, the determination of the guilt of an offender with respect to the commission of an offence and the judicial sentencing of an offender. The determination of the guilt of an offender is predicated on the presence of criminal responsibility which includes the physical and mental elements of actus reus and mens rea respectively. (Onoyiwa $v$ State) Criminal responsibility means criminal liability, and it presupposes that a person should only be punished for an offence committed where it can be proved that the act was a crime and the offender had the capacity to appreciate the quality of his actions (Gardner 2008). This gives a valid explanation as to why defences to criminal charges are capable of exculpating a defendant from the criminal charges that have been preferred against him or her because such defences offer the defendant an opportunity to deny the existence of either the actus reus or the mens rea elements of the offence (Colvin, 1990). The Criminal Code Act under Chapter 5, titled 'Criminal Responsibility' carefully addresses certain defences which can be raised by a defendant in defence to different crimes (Sections 22-36) and one of those defences is the defence of immature age. The focal point of this paper is to critically consider the defence of immature age or doli incapax provided for under Section 30 of the Criminal Code.

This paper has been structured into four (4) parts. The first part is the introduction; the second part examines the jurisprudence of the doctrine of doli incapax; the third part examines the application of the doctrine of doli incapax in the Nigerian legal system and its pitfalls; and the fourth part of the paper is the conclusion.

\section{The History and Jurisprudence of the Doctrine of doli incapax}

As earlier mentioned, the basis for the conviction of a defendant for an offence is that it must be established that the defendant, at the time of the commission of the offence must have had the requisite physical and mental elements of a crime. The doctrine of doli incapax, however posits that, a child by virtue of his mental status, is incapable of committing a crime.(Arthur 2010: 43) Thus, the defence of doli incapax excludes children within a particular age range from criminal responsibility on the ground that they lack the requisite capacity to commit an offence.(Arthur 2010: 43) Doli incapax seeks to negate the presence of the mental element of an offence by asserting that while it is possible that a child commits an offence, it is not possible for such child to be considered criminally liable for his/her acts or omissions because such child lacks sufficient capacity to appreciate the nature and consequences of his acts or omissions.(Simic \&Kazic, 2017) The doctrine therefore, creates a minimum age 
of criminal responsibility, below which no child can be held accountable for his criminal acts or omissions. (Arthur 2010: 43)

The origin of the doctrine of doli incapax is quite complex as it cannot be specifically attributed to a particular source. However, the doctrine is applicable in both Civil law and Common law jurisdictions. (Fitz-Gibbons, K \& O'Brien, W. 2019; Crofts T. 2016). Its development in the Civil law legal system can be attributed to the early Roman laws which had made special provisions for children below certain ages to protect them from the rigours of the Roman penal law and contractual obligations. (Muirhead, 2009:46) Roman law translated the presumption that children are deemed incapable of committing offences, committing a tort, and entering into legal transactions as the doctrine of doli incapax. (Muirhead, 2009: 391) Under the Roman law, where a child that was below the age of puberty entered into transactions with other individuals, such transactions will be declared void. In the same vein, where such child committed an offence, he will be absolved from liability. (Muirhead, 2009: 291) Children were accorded a vulnerable status which allowed them the benefit of certain preferential treatments where their liability for certain acts or omissions came into question. (Muirhead, 2009: 391). The reasoning behind this approach is that children are considered incapable of determining the quality of their action, that is, whether the actions are right or wrong.

The pre-Norman laws of Ine that were applicable during the 12th century stated that the age of ten (10) years old should be the age of minimum criminal responsibility and children that were below that age were deemed incapable of committing any offence (Arthur 2010: 44). The 10th century laws of Athelstan that were drafted by a bishop, had provided that a thief should not be spared punishment if he is over twelve (12) years old (Arthur 2010: 44). This means that where a thief was found to be above the age of twelve (12), he was liable to be punished according to the dictates of the penal law. Although Bracton does not stipulate a specific minimum age of criminal responsibility, he however, posited that children are protected from criminal law as a result of their 'harmless intention'(Bandalli,1998). In the 15th century, prior to the Norman conquest of England, the minimum age of criminal responsibility was lowered to seven (7) years of age (Arthur,2010:44). Young offenders were subjected to similar trials and mode of punishments that their adult counterparts were exposed to (Arthur,2010:44). This included the imposition of capital conviction, transportation and imprisonment of child offenders. The position of the law during this period can be aptly summarised as: if a child was competent to commit an offence, he was competent enough to be sentenced the same way as adults.

Thus, the pre-Common Law era provided no exact age at which a child should be held criminally responsible for his actions or omissions (The Law Reform Commission of Hong Kong. 1999). This uncertainty in the law led to the meting out of punishments to children who were under the age of seven (7) years based on their ability to distinguish between what is right and what is wrong (The Law Reform Commission of Hong Kong. 1999). Even after the development of Common law and during its formative years, the Common law judges wielded the discretion to determine if a child had attained the age of criminal responsibility or not (The Law Reform Commission of Hong Kong. 1999).

In 1619, Dalton CJ stated that:

'an infant of eight years of age or above may commit homicide and shall be hanged for it, viz, if it may be appear (by hiding of the person slain, by excusing it or by any other act) that he had knowledge of good and evil and of the peril and danger of that offence. But an infant of such tender years, as that he hath no discretion or intelligence, if he kills a man, that is no felony of him' (Dalton, 1661)

According to Photis, (Photis, 1987) in the Anglo-Saxon period, a child cannot be found guilty of a crime if such child had not attained the age of twelve (12) years old. During the reign of Edward I, this was reduced to seven (7) years old. In 1933, Section 50 of the Children and Young Persons Act, 1933 (England), raised the age of criminal responsibility from seven (7) to eight (8) years. The age of criminal responsibility was further raised in Section 16 of the Children and Young Persons Act, 1963 (England) from eight (8) years to ten (10) years. This meant that children that were below the age of ten (10) years enjoyed the benefit of the presumption of doli incapax. Section 4 of the Crime and Disorder Act, 1998 has abolished the presumption of doli incapax created under the Children and Young Persons Act, 1963.

The doctrine of doli incapax has found expression in the provisions of the statutes of different countries including Nigeria through the introduction of the minimum age of criminal responsibility which varies from one country to another, but ensures that children below a particular age range cannot be held liable for certain criminal behaviours. The defence has been held to be anchored on a principle of public policy which seeks to safeguard the interests of a child especially where such child cannot appreciate the quality and implications of his/her actions (Lennings, 2013). Professor Hart towing a similar pattern of logic commented that:

'What is crucial is that those whom we punish should have had, when they acted, the normal capacities, physical and mental, for doing what the law requires and abstaining from what it forbids, and a fair opportunity to exercise these capacities. Where these capacities and opportunities are absent. ... the moral protest is that it's morally wrong to punish because 'he 
could not have helped it', or 'he could not have done otherwise' or 'he had no real choice'"1(Hart, 2008)

Hawkins, adopting Hart's position maintained that 'the capacity of contracting guilt is measured more by the apparent strength of the offender's understanding than by years and days.' Professor Hart's remark lends credence to the rationale behind the doctrine of doli incapax as it ensures that the mental capacity of offenders at the point of the commission of the offence be taken into consideration; and the doctrine of doli incapax advocates that children by reason of their age and reasoning do not possess sufficient mental capacity to appreciate the quality of their actions or omissions (Hawkins, 1795).

\section{Application of the Doctrine of doli incapax in Nigeria}

The dual nature of the Nigerian legal system has largely influenced the operation of two (2) different streams of criminal law within the Nigerian territory as different statutory regimes of criminal law operate in the Northern and Southern regions of Nigeria. (Yancey, 1987). The Criminal Code Act is operative in the Southern region of Nigeria, while the Penal Code Act is only applicable in the Northern region of Nigeria. (Yancey, 1987) Although the provisions of both statutes are quite similar with respect to certain matters, there are nevertheless some areas of divergence between both statutes, one of which is the doctrine of doli incapax. To fully grasp the idea of the divergent positions of the Criminal Code and the Penal Code on the application of the doctrine of doli incapax in Nigeria, it is imperative that the provisions of both statutes on the subject matter are considered.

The doctrine of doli incapax, otherwise known as the defence of immature age, is provided under Section 30 of the Criminal Code Act which states that:

A person under the age of seven years is not criminally responsible for an act or omission

A person under the age of twelve years is not criminally responsible for an act or omission, unless it is proved that at the time of doing the act or making the omission he had capacity to know that he ought not to do the act or make the omission

A male person under the age of twelve years is presumed to be incapable of having carnal knowledge.

The provision of Section 30 of the Criminal Code is tripartite in nature, as it contains three (3) distinct statements of law on the defence of immature age or the doctrine of doli incapax. The first proposition of law provides a general statement of law that persons that are under the age of seven (7) are not capable of committing any offence. Section 2 of the Criminal Code Act defines an 'offence' as an act or omission which renders the person doing the act or omission liable to punishment under the Code.

The second proposition of law states that a person under the age of twelve (12) cannot be criminally held liable for his acts or omissions except it can be established that at the time of carrying out such acts or omissions, such person was seized with the requisite mental capacity to understand the implications of his actions. The third proposition of law then states that a 'male person' under the age of twelve (12) is deemed incapable of having carnal knowledge, that is, committing the offence of rape. Criminal Code Act, Section 6 provides that 'when the term 'carnal knowledge' or the term 'carnal connection' is used in defining an offence, it is implied that the offence, so far as regards that element of it, is complete upon penetration.

Before examining the implications of these statements of law, it is important to note that the provisions reproduced above are only applicable to children. Although it might seem quite apparent and in line with common sense that these provisions are applicable to children, but it is submitted that the basis for this conclusion is premised on the provisions of the Child Rights Act 2004, Section 277 and the Children and Young Persons Act, Section 2 (which is still applicable to States that have not yet domesticated the Child Rights Act which define a 'child' as a person that is below the ages of eighteen (18) and fourteen (14) years respectively. Therefore, since the age brackets mentioned within the provision of Section 30 of the Criminal Code Act fall below the minimum age provided under the Child Rights Act and the Children and Young Persons Act, persons whom Section 30 is applicable to will be considered 'children' for the purposes of the Criminal Code and other laws.

A community reading of the tripartite provision of Section 30 of the Criminal Code portrays the operation of the presumptions of law whether rebuttable or irrebuttable. The first provision of Section 30 asserts that children below the age of seven (7) years cannot commit an offence and this assertion is an irrebuttable presumption of law because it gives no room for disproving the assertion. (David \& Nsereko, 2011) Although it has been affirmed that there is no clear-cut judicial pronouncement in Nigeria declaring the first limb of Section 30 an irrebuttable presumption, it is however, apparent from a contextual reading of the three limbs of Section 30 that an irrebuttable presumption has been created under the first limb (AjaNwachuku \& Faga, 2016). The implication of the presumption being irrebuttable is that even where there is positive evidence, showing that a child is guilty and had the requisite capacities at the time of the commission of the offence, such evidence will not be admissible, and if admissible, it will be discountenanced by the court. (Osborough,1997; Sharma,1970) Thus, a child might have 
actually committed the offence of rape, possessing the requisite physical and mental elements, but the law will deem such child incapable of committing the crime.

The second proposition of law, however, is a rebuttable presumption of law as it provides that unless otherwise shown that the child had sufficient mental capacity at the time of the act or omission, a child below the age of twelve (12) cannot commit any offence. (Oraegbuna, I.K. (2011) The implication of this proposition is that there is a dual legal obligation on the prosecution. The prosecution must not only establish that the child committed the offence, but they must also establish that the child had the capacity to know that what he/she was doing at the relevant time was wrong. (Johnston, M. 2006) Thus, where the prosecution can provide relevant evidence portraying the guilty knowledge of the child, the Court would displace the operation of the presumption of doli incapax.

The third statement of law, unlike the second is specific and provides for an irrebuttable presumption of law as it states that a male child that is below the age of twelve (12) cannot commit the offence of rape. The fact that this provision contains an irrebuttable presumption can be logically deduced from the second statement of law which has provided a general proposition as to the fact that children under the age of twelve (12) years are incapable of committing any offence unless it can be shown that they had sufficient mental capacity at the time of the commission of such offence. From this, it is apparent that the second ambit of the provision of Section 30 of the Criminal Code gives room for disproving the general statement of law it provides for, especially in the face of overwhelming positive evidence which points to the contrary. However, the third ambit of the provision of Section 30 of the Criminal Code is a specific statement of law which derogates from the preceding provision. In the case of Adedayo \& Ors v. PDP \& Ors (2013) the Supreme Court held that the law is well settled that a specific statement of law will always override a general statement of law. The same principle has been enunciated in a plethora of cases such as Ibori v. Ogburu (2004); M. V. Panormos Bay \& Drs. v. Olam Nigeria Plc. (2004); Shroeder \& Co. v. Major \& Co. Ltd. (1989) and Kraus Thompson Organisation v. National Institute for Policy and Strategic Studies (NIPSS) (2004).

Thus, while a child under the age of twelve (12) with the requisite physical and mental element may be convicted of the offence of murder, such child cannot be convicted of the offence of rape because of the third statement of law under Section 30 of the Criminal Code Act.

However, under the Penal Code Act, Cap P8 LFN 2004, the legal context is quite different. Section 50 of the Penal Code Act provides that:

No act is an offence, which is done by:

(a) A child under the age of seven

(b) child above seven years of age but under twelve years of age who has not attained sufficient maturity of understanding to judge the nature and consequence of such act.

From a careful perusal of the provision of Section 50(b) of the Penal Code, it is evident that the Penal Code creates a rebuttable presumption of law for children within the age bracket of seven to twelve (7-12) without exculpating any child from liability for an offence if it can be proven that such child had attained sufficient maturity of understanding to understand the nature and consequences of his acts. The Penal Code unlike the Criminal Code does not create any exception for the liability of children below the age of twelve (12) for the offence of rape. One of the underlining reasons which may have influenced the reasoning of the drafters of the Criminal Code to create an irrebuttable presumption for children under the age of twelve (12) with respect to the offence of rape might have been the fact that it was believed that children within such age are physically impossible of committing the offence of rape at that phase. (AjaNwachuku \& Faga: 587) However, it is submitted that this is untrue based on the pieces of scientific evidence which are available. (Donaldson, J., Rees R. \& Steinbrecher, H. 2014) Not to bore with scientific details which might obscure the importance of the point being made, a crucial element of the offence of rape needed for the conviction of an offender is penetration and not ejaculation of semen. A healthy child under the age of twelve (12) is capable of fulfilling the requirement of penetration which is all that the law requires as actus reus for the offence of rape. In fact, Glanville Williams (Williams, G. 1983) heavily criticised the notion that a child under the age of fourteen (14) is incapable of having sexual intercourse when he observed that:

The other person who cannot be convicted of rape is a boy under 14, the reason advanced being that he is irrebuttably presumed not to have reached the age of puberty. This fiction is doubly silly. First, puberty may be attained before 14, and secondly, puberty is not necessary for rape. Rape requires only penetration, not fertilisation, so that it is only an ability to have an erection, not an ability to emit semen that is physically necessary for the crime.

The situation presented by Section 30 of the Criminal Code is quite absurd as it presumes that a male child under the age of twelve (12) is incapable of committing the offence of rape, but admits the possibility that a child within the same age bracket could be liable for the offence of murder, theft, indecent assault, and other heinous crimes. The question that disturbs the reasonable mind is, what makes the offence of rape exceptional that the Criminal Code has excluded children under the age of twelve (12) from liability for the offence? The answer is 
nothing. One may suggest that the argument, albeit countered by Glanville, that children under the age of twelve (12) might not have attained puberty might have constituted a deciding factor on the mind of the drafters of the Criminal Code which might have influenced their decision to incorporate such provision into the Criminal Code.

It is submitted that the third ambit of Section 30 of the Criminal Code which exculpates children under the age of twelve (12) from liability for the offence of rape is anachronistic and does not conform to the realities of the 21 st century which is characterised by different shades of indecent exposure that may influence the minds of children with respect to their acts or omissions. (Finkelhor, Ormrod, \& Chaffin,2009)

The Cambodian juvenile rape case buttresses this position. In that case which occurred in 1999, a girl named 'Thany' who was about seven (7) years old was invited by another girl named 'Dara' to come play at their neighbour's house. Although Thany was reluctant to go, but her mother urged to go with Dara to play. After playing for a while, Dara suggested they go to the pond to wash, and when they finished washing, Thany rushed to go home, but Dara called to her brother that Thany was getting away. The brother came and caught Thany, covered her mouth and dragged her to some nearby palm trees. He then told Dara to go get a mat and scarves. The boy called over two of his friends who were aged twelve (12) and thirteen (13) and they forced Thany to lie down on the mat laid by Dara, tied a scarf around her (Thany's) mouth, then tied her hands to the end of a piece of wood which they laid across her chest. They tied her legs apart, then each boy proceeded to rape her, two times each. While this was going on, Dara was sitting a short distance away watching and keeping look out. The boys then took Thany to the pond and again tied her and raped her two times each. Thany was traumatized by the ordeal and suffered injuries to her genital area. She was referred for medical and psychiatric treatment by Cambodian League for the Promotion and Defence of Human Rights (LICADHO), who also intervened to get the police to arrest the boys, who until then were still living freely in the village near to the victim. On investigation it was discovered the three boys had been watching pornography at a local video bar, and it appears they copied actions they had seen on video.

\section{Conclusion}

This paper has examined Section 30 of the Criminal Code Act which provides for the defence of immature age or the doctrine of doli incapax. In a bid to expose some of the inconsistencies inherent in the provision of the Criminal Code in relation to the doctrine of doli incapax, this paper compared and contrasted the provisions of Section 30 of the Criminal Code with that of Section 50 of the Penal Code. One of the findings from this comparative exercise which constitutes the focal point of this paper is that the Criminal Code exculpates children under the age of twelve (12) from criminal liability for the offence of rape which is not what is obtainable under the Penal Code. There are no justifications whatsoever in the realms of law, logic and morality which support the reasoning of the drafters of Section 30 of the Criminal Code as the provision has a huge tendency of encouraging rather than discouraging sexual offences like rape among minors. To avoid the disintegration of the moral fabric of the society through the letters of the law, it is submitted that the provision of Section 30 of the Criminal Code be amended to align with the position under Section 50(b) of the Penal Code. The dynamism and complexity of the modern society necessitates this amendment as the law must reflect the realities of the ever-changing society.

\section{References}

Adedayo \& Ors. v. PDP \& Ors (2013) LPELR-20342 S.C.

AjaNwachuku, M.A. \& Faga, H.P. (2016) Perpetration of the Offence of Rape by Minors in Nigeria: A Call for Legislative Re-statement of the Law. 13(8) US-China Law Review: 585-587.

Arthur, R. (2010) "The Age of Criminal Responsibility and the Defence of doli incapax", in Arthur, R. (ed.) Young Offenders and the Law: How the Law Responds to Youth Offending, Routledge :43.

Bandalli, S. (1998) "Abolition of the Presumption of doli incapax and the Criminalisation of Children," 37(2) Harvard Journal of Criminal Justice: 114-123

Child Rights Act, C50 Laws of the Federation of Nigeria (LFN) 2004

Children and Young Persons Act, 1933 (England)

Children and Young Persons Act, 1963 (England)

Children and Young Persons Act, Cap 485 LFN 1990.

Colvin, E. (1990) "Exculpatory Defences in Criminal Law," 10(3) Oxford Journal of Legal Studies: 381.

Crime and Disorder Act, 1998

Criminal Code Act, Cap C 38 Laws of the Federation of Nigeria (LFN) 2004

Crofts, T. (2016) "The Common Law Influence Over the Age of Criminal Responsibility in Australia," 67(3) Northern Ireland Legal Quarterly: 283.

Dalton, M. (1661) The Country Justice: Containing the Practice of the Justices of the Peace out of their Sessions: gathered for the Better Help of Such Justices of Peace as have not Been much Conversant in the Study of the Laws of this Realm, Company of Stationers, 307.

David, D. \& Nsereko, N. (2011) Criminal Law in Botswana, Hague: Wolters Kluwer Publishers: 94. 
Donaldson, J., Rees R. \& Steinbrecher, H. (2014) "Priapism in Children: A Comprehensive Review and Clinical Guideline." 10 Journal of Paediatric Urology, 11-25.

Dubber, M. (2000) Criminal Law: Model Penal Code, New York University Press: 5.

Finkelhor, D. Ormrod, R. \& Chaffin, M. (2009) "Juveniles who commit sex offenses against minors." Office of Juvenile Justice and Delinquency Prevention:2-4.(Online) Available: https://www.ncjrs.gov/pdffiles1/ojjdp/227763.pdf. (10 February 2020)

Fitz-Gibbons, K. \& O’Brien, W. (2019) “A Child's Capacity to Commit Crime: Examining the Operation of doli incapax in Victoria (Australia)," 10(1) International Journal for Crime, Justice and Social Democracy:8

Gardner, J. (2008) Offences and Defences: Selected Essays in The Philosophy of Criminal Law, Oxford University Press: 112.

Hart, H. L. A., (2008) Punishment and Responsibility: Essays in the Philosophy of Law, Oxford University Press: 152.

Hawkins, W. (1795) A Treatise on the Pleas of the Crown: A System of the Principal Matters Relating to that Subject, Digested under Proper Heads, 7th edition, G.G. and J. Robinson, 45.

Ibori v. Ogburu (2004) 15 NWLR (Part 895) 154

Johnston, M. (2006) The Criminal Responsibility of Children, Children's Law News 1.

Kraus Thompson Organisation v. National Institute for Policy and Strategic Studies (NIPSS) (2004) 17 NWLR (Part 901) 44.

Lennings, J. (2013). “Assessing Serious Harm under the Doctrine of doli incapax: A Case Study,”21(5) Psychiatry, Psychology and Law: 791-800.

M. V. Panormos Bay \& Drs. v. Olam Nigeria Plc. (2004) 5 NWLR (Part 865) 1

Muirhead, J. (2009) Historical Introduction to the Private Law of Rome. Goudy, H. \& Grant, A. (eds.), Lawbook Exchange Ltd.: 46.

Onoyiwa v State (2018) LPELR-44255 C.A.

Oraegbuna, I.K. (2011) Mens Rea Principle and Criminal Jurisprudence in Nigeria'. 2 Nnamdi Azikiwe University Journal of International Law and Jurisprudence: 225

Osborough, N. (1997) Rebutting the Presumption of 'doli incapax'. 10(1) Irish Jurist New Series: 548-58

Penal Code Act, Cap P8 LFN 2004

Photis, A.D. (1987). Criminal Responsibility of Infants, Justice of the Peace: 263.

Rape and indecent assault in Cambodia. (online) Available: https://www.licadhocambodia.org/reports/files/45Summarized\%20rape\%20report.pdf (10 February, 2020)

Sharma, V. (1970) The Criminal Responsibility of Children. 3 Anglo-American Law Review, 157

Shroeder \& Co. v. Major \& Co. Ltd. (1989) 2 NWLR (Pt.101)21

Simic, G. \& Kazic, E. (2017) "Legal Challenges in Regulation of Minimum Age of Criminal Responsibility with Special Emphasis on Bosnia and Herzegovina,” 10(1) Journal of Transdisciplinary Studies: 43.

The Law Reform Commission of Hong Kong. (1999) The age of criminal responsibility in Hong Kong. Retrieved on January 31, 2020 from < http://www.info.gov.hk/archive/consult/1999/age-e.pdf >

Williams, G. (1983) Textbook of Criminal Law, 2nd Ed. Steven \& Sons: 638

Yancey, E.M. (1987) The Administration of Criminal Justice in the United States and the Federal Republic of Nigeria: A Comparison, 10(1) National Black Journal 91. 